\title{
TELAAH ULANG HAK PAKSA DALAM PERKAWINAN ISLAM MELALUI PENDEKATAN FIQH, MUNÂSIB AL-'ILLAH DAN 'URF
}

\author{
Moh. Dliya'ul Chaq \\ Institut Agama Islam Bani Fattah Jombang, Indonesia \\ E-mail: yayakrafi@gmail.com@gmail.com
}

\begin{abstract}
The provision ijbâr Rights in Islam has become the legal umbrella of forced marriage implementation in a deep-rooted society. The existence of unbalanced understanding and strong indication of the influence of 'urf. Through fiqh approach, munâsib al-'illah and 'urf focusing on review of forced reextrictions in Islamic law, obtained that right ijbâr is actually a safeguard against girls but when it becomes a guardian's right, it can not be applied because; right of girl in the fiqh salaf takes precedence over the right of guardians as the provisions of guardians 'adal and the requirements of the guardian of mujbîr; legal images of the nature of girl and nature of children in the study of munâsib al-illah with the approach of alqawâ'id al-fiqhîyah has one point of similarity that 'illat is immature in sense of not being able to determine maṣlahah herself that shows maqâșid avoids girls from danger, and this is difficult to achieve by forced marriage; the basic law of the right of ijbâr is the hadith that 'illat in hadith it is 'urf so that the hadith's validity depends on 'urf; and deliberation between guardians and girls is the best and praiseworthy way of determining a potential mate.
\end{abstract}

Keywords: Ijbâr Rights, Islamic Marriage, Fiqh, Munâsib al-'Illah, 'Urf

\section{Pendahuluan}

Hukum perkawinan Islam di Indonesia dan beberapa Negara yang masyarakatnya muslim memang telah dilegalkan dalam bentuk undangundang. Namun demikian, bukan berarti hukum perkawinan Islam tersebut tidak luput dari problem dan kritik. Terlebih di Indonesia di mana hukum perkawinan Islam dalam Undang-Undang Nomor 1 Tahun 1974 Tentang Perkawinan dan juga Kompilasi Hukum Islam (KHI) terdapat beberapa hukum yang dinilai bertentangan dengan figh salaf, di antaranya terkait usia nikah, ketentuan anak sah, dan termasuk juga 
tentang nikah paksa. Hal ini kemudian mendorong para ahli hukum dan akademisi untuk melakukan kajian-kajian ilmiah.

Terkait nikah paksa, dalam hukum Islam dinyatakan bahwa wali memliki hak paksa (hak ijbâr) sehingga muncul istilah wali mujbîr, yaitu wali yang berhak memaksakan pernikahan pada anaknya. ${ }^{1}$ Ketentuan wali mujbî pada akhirnya menjadi payung hukum bagi pelaksanaan nikah paksa di masyarakat yang bahkan telah mengakar. Sementara bagi masyarakat modern saat ini, ketentuan semacam itu tentu dipertanyakan sebab banyak nilai-nilai modernitas yang dilanggar semisal hak asasi manusia, hak asasi perempuan dan hak asasi anak. Begitupun jika dilihat dari sisi asas syariah, hak paksa wali terlihat menyalahi asas tidak ada paksaan dalam beragama.

Teramati bahwa pemahaman tentang wali mujbîr di masyarakat tidak diimbangi dengan pemahaman terhadap hukum wali adal. Padahal jika diamati lebih lanjut, hukum tentang wali adal merupakan hukum yang harus disandingkan dengan hukum wali mujbîr secara berimbang dan adil, sebab hukum wali adal merupakan bentuk hukum perlindungan terhadap hak sang anak. Sementara hukum wali mujbîr adalah perlindungan terhadap hak wali namun disertai syarat-syarat yang ketat. Selain itu, ketentuan hukum wali mujbir terindikasi kuat adanya pengaruh 'urf di dalamnya. Sebagaimana ungkapan Nasaruddin Umar bahwa karya fiqh klasik terpengaruh dan terikat dengan kondisi sosial budaya yang melingkupi tempat perumusannya. ${ }^{2}$ Termasuk ketentuan hak ijbâr menurutnya tergolong bias gender di kawasan Jazirah Arab karena meniadakan otoritas perempuan untuk menentukan pilihannya. ${ }^{3}$ Oleh karena dua hal inilah artikel ini bertujuan untuk menelaah ulang hak paksa wali dalam perkawinan melalui pendekatan fiqh, munâsib al-illah dan' 'urf.

\section{Ketentuan Hukum Hak Ijbâr dan Wali Mujbîr}

Hak jjbâr adalah istilah yang muncul dari adanya istilah wali mujbir dalam hukum Islam. Wali mujbîr menurut Shaykh Abû Bakr Muhammad al-Shațâ adalah wali (ayah atau kakek) yang berhak memaksakan pernikahakan pada anaknya. ${ }^{4}$ Maka hak ijbâr adalah hak yang dimiliki wali

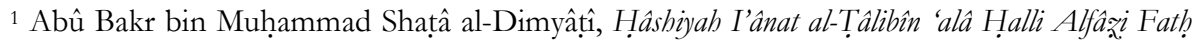
al-Mu'în, (Beirut: Dâr Ibnu 'Aș̣̂așạah, 2005), Vol. III, 353-354.

2 Nasaruddin Umar, Argumen Kesetaraan Jender Perspektif Al-Qur'an, (Jakarta: Dian Rakyat, 2010), 271.

${ }^{3}$ Nasaruddin Umar, Argumen Kesetaraan, 125.

${ }^{4}$ Abû Bakr bin Muhammad Shatâa al-Dimyâtî̀, Hệshiyah, Vol. III, 353-354.
} 
(ayah atau kakek) untuk memaksakan pernikahan pada anak perempuannya.

Pendapat fuqahâ, perempuan yang boleh dipaksa oleh wali untuk menikah adalah anak gadis dewasa (al-bikr al-bâlighah), anak gadis kecil (albikr al-saghirah) dan janda yang masih kecil (al-thayyib al-saghirah). Adapun janda yang sudah dewasa, fuqahâ' seluruh madhhab sepakat untuk tidak menggolongkannya sebagai perempuan yang dapat dipaksa untuk menikah oleh walinya. ${ }^{5}$ Dalam pandangan fuqabâ, janda memiliki otoritas hak penentu nikah sehingga tidak dapat dipaksa menikah oleh siapapun. Bahkan jika dipaksakan, janda berhak menolak pernikahan tersebut. Begitupun ketika wali tidak berkenan menikahkannya dengan calon pilihan janda tersebut maka perwaliannya berpindah pada wali hakim sebagaimana dilâlab dari ḅadîth Rasulullah SAW, berikut redaksi ḅadîth tersebut:

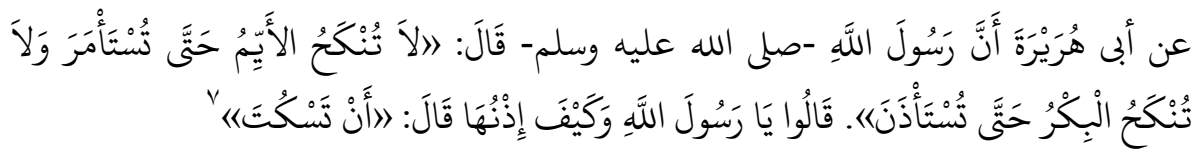

Artinya: Hadîth riwayat Abû Hurairah bahwasannya Rasulullah SAW bersabda: "Tidak dinikabkan seorang janda sampai diminta perintahnya, dan tidak dinikabkean seorang gadis sampai diminta persetujuannya." Lalu para sahabat bertanya: "Bagaimana bentuk persetujuan gadis?" Rasul menjawab: "Diamnya".

Hadîth lain:

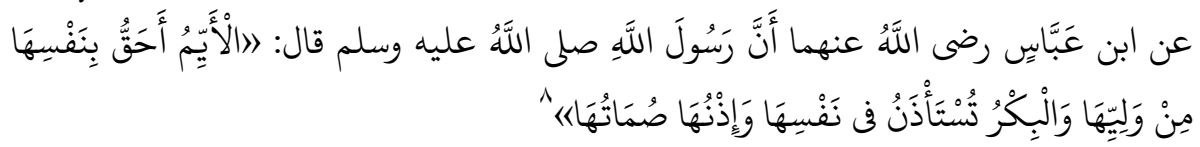

\footnotetext{
${ }^{5}$ Muhammad Ibn al-Ḥasan al-Shaybânî, al-Hujjah 'alâ Abli al-Madînah, (Beirut: Dâr al-Kutub al-Ilmiyyah, 1990), Vol. III, 126., Al-Sarkhasî, al-Mabsût li al-Sarkhasî, (Beirut: Dâr al-Fikr, 2000), Vol. IV, 180, dan lihat Vol. V, 3., Muhammad Ibnu Idrîs al-Shâfi'î, al-Um, (Beirut: Dâr al-Ma'rifah, 1993), Vol. V, 167, dan Muḥyi al-Dîn Yahyâ Ibnu Sharaf al-Nawâwî, alMajmû' Sharh al-Muhadhdhab, (Beirut: Dâr al-Fikr, 1990), Vol. 16, 165.

${ }^{6}$ Al-Sarkhasî, al-Mabsût li al-Sarkhasî, (Beirut: Dâr al-Fikr, 2000), Vol. V, 9.

7 Aḥmad Ibnu Hanbal, Musnad Aḥmad Ibnu Hanbal, (t.tp.: Muassasah al-Risâlah, 1999), No. Indeks 9603, Vol. II, 434., Muhammad Ibnu Ismâ̂̂l al-Bukhârî, al-Jâmi' al-Sabị̂̉, (Beirut: Dâr Ibnu Kathîr, 1987), No. Indeks 4843, 6769, 6567, bab al-Nikâh, Vol. V, 1574., Imam Muslim, al-Jâmi' al-Ṣahîh, (Beirut: Dâr al-Jayl, t.th.), No. Ideks 3538, Vol. IV, bab al-Nikâh, 140.

8 Abû Daud, Sunan Abû Daud, (Beirut: Dâr al-Kitâb al-'Arabî, t.th.), Vol. II, No. Indeks 2100, 196., Muhammad ibnu 'Îsâ al-Tirmidhî, Sunan al-Tirmidhî, (Beirut: Dâr Ihyâ' al-Turâth, t.th.), Vol. III, No. Ideks 1108, 416., Imam Muslim, al-Jâmi’ al-Saḥ̂h, (Beirut: Dâr al-Jayl, t.th.), Vol. IV, No. Ideks 3541, 141. Musnad Aḥmad Ibnu Ḥanbal, (t.tp.: Muassasah al-
} 
Artinya: Hadîth riwayat 'Abdullah Ibn 'Abbâs bahwasannya Rasulullah SAW bersabda: "Perempuan janda lebih berbak atas dirinya daripada walinya, sedangkan anak gadis diminta persetujuannya atas dirinya, dan persetujuanny a dalah diamnya".

Bahkan dalam dilalah hadith yang lain, Rasul melakukan pembatalan perkawinan paksa terhadap janda, sebagaimana riwayat Ibnu Abbas:

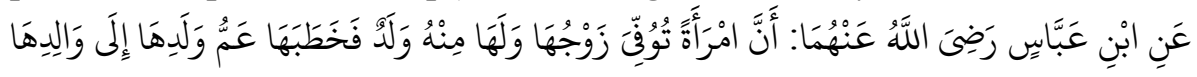

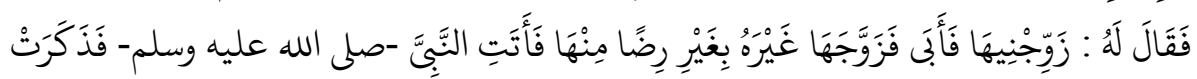

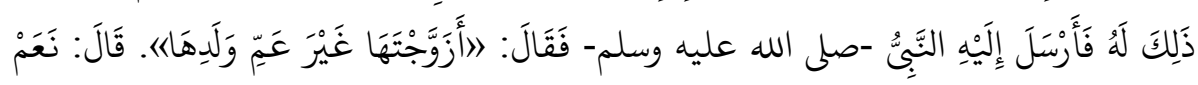

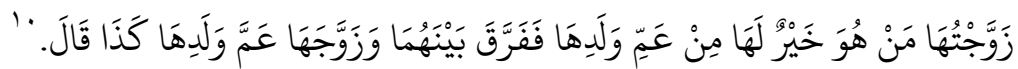

Artinya: Hadîth riwayat Ibnu 'Abbâs babwa perempuan yang suaminya meninggal memiliki satu anak dilamar oleb laki-laki paman dari anak-anaknya melalui ayahnya. Laki-laki tersebut berkata pada ayah janda tersebut: Nikabkanlah aku dengannya. Tetapi ayahnya tidak berkenan dan menikabkannya dengan laki-laki lain tanpa persetujuannya. Lalu perempuan janda tersebut melaporkan pada Rasulullah SAW. Lalu Rasulullah memanggil ayahnya dan bertanya: Apakah kau naikabkan anakmu dengan selain paman dari anak-anaknya? Ayahnya menjawab: Iya, aku nikabkean dengan orang yang lebih baik darinya. Lalu Rasulullab SAW memisabkan keduanya dari pernikaban tersebut dan menikabkan dengan paman dari anak-anaknya"

Sedangkan tentang ijbâr wali terhadap gadis dewasa (al-biker al-bâlighah), terdapat dua pendapat fuqahâ'. Pendapat pertama mengatakan bahwa wali berhak memaksakan pernikahan pada gadis dewasa tanpa persetujuannya. Pendapat ini disampaikan oleh mayoritas fuqahâ' madhhab mâlikîyah diantaranya Imam Mâlik, Abû 'Umar Yûsuf Ibnu 'Abdillah Ibnu Muhammad Ibnu 'Abd al-Bar Ibnu 'Âṣim al-Namrî alQurṭ̂bî̀, Abû al-Ḥasan 'Alî ibnu 'Abd al-Salâm al-Tasûlî," fuqahâ'

Risâlah, 1999), Vol. I, No. Indeks 1888, 1897, 2163, Mâlik Ibn Anas, al-Muwaț̣a', (Beirut: Dâr al-Kutub al-'Alamiyyah, 2006), No. Indeks 1914, 427.

${ }^{9}$ Al-Sarkhasî, al-Mabsût li al-Sarkhasî, (Beirut: Dâr al-Fikr, 2000), Vol. V, 9.

10 Aḥmad Ibnu al-Khusayn al-Bayhaqî, Sunan al-Bayhaqî al-Kubrâ, (Mekkah: Maktabat Dâr alBâz, 1994), No. Indeks 14057, Vol. VII, 120. Hadîth ini menurut al-Bayhaqî tergolong mursal sahabat dengan mutu sahị̣̂.

${ }^{11}$ Mâlik Ibn Anas, al-Muwatta', (Beirut: Dâr al-Kutub al-'Alamiyyah, 2006), No. Indeks 1914, 427, Abû 'Umar Yûsuf Ibnu 'Abdillah Ibnu Muhammad Ibnu 'Abd al-Bar Ibnu 'Âṣim alNamrî al-Qurțûbi, al-Kâfî fî Fiqh Abl al-Madinah, (Riyaḍ: Maktabat al-Riyậ al-Hadîthiyyah, 1980), Vol. II, 523-524., Abû 'Umar Yûsuf al-Namrî al-Qurț̂ibî, al-Istidbkâr al-Jâmi' li 
madhhab shâfi'iyyah di antaranya Imam al-Shâfi'î, al-Nawâwî, al-Khaṭ̂ib alSharbînî dan Mûsâ al-Hịiâwi, ${ }^{12}$ dan sebagian fuqahâ' madhhab ḥanâbilah diantaranya Ibnu Qudâmah, Bahâ' al-Dîn al-Maqdisî dan salah satu pendapat Ibnu Hạanbal. ${ }^{13}$ Dasar yang gunakan kelompok ini adalah ḥadîth Rasulullah SAW:

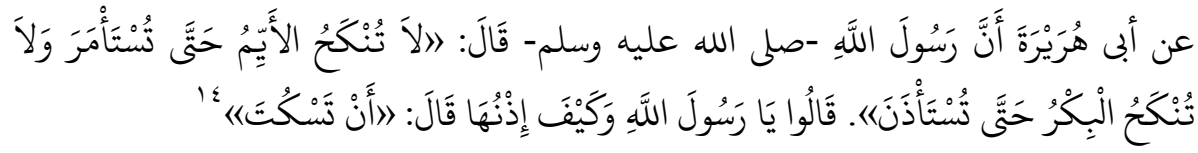

Artinya: Hadîth riwayat Abu Hurayrah bahwasannya Rasulullah SAW bersabda: "Tidak dinikabkan seorang janda sampai diminta perintahnya, dan tidak dinikabkan seorang gadis sampai diminta persetujuannya. Lalu para sahabat bertanya: Bagaimana bentuk persetujuan gadis? Rasul menjawab: Diamnya"

Hadith lain:

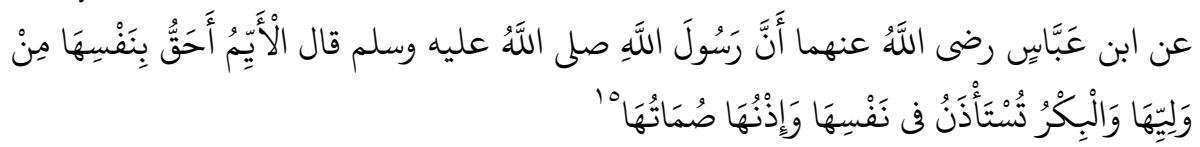

Artinya: Hadîth riwayat 'Abdullah Ibnu 'Abbâs bahwasannya Rasulullah SAW bersabda: "Perempuan janda lebih berbak atas dirinya daripada

Madhâhib Funqahâ’ al-Amsâr, (Beirut: Dâr al-Kutub al-'Ilmiyyah, 2000), Vol. V, 389., Abû alWalîd Muhammad ibnu Aḥmad ibnu Rushd al-Qurtûbî al-Andalûsî, Bidâyat al-Mujtabid wa Nihâyat al-Muqtasid, (Bierut: Dâr al-Fikr, t.th.), Vol. II, 4., Abû al-Ḥasan 'Alî ibnu 'Abd alSalâm al-Tasûlî, al-Babjah Sharḥ al-Tuhfah, (Beirut: Dâr al-Kutub al-'Ilmiyyah, 1998), Vol. I, 421.

12 Muhammad Ibnu Idrîs al-Shâfî̀, al-Um, (Beirut: Dâr al-Ma'rifah, 1993), Vol. V, 18., Muhyi al-Dîn Yahyâ Ibnu Sharaf al-Nawâwî, al-Majmû' Sharḥ al-Mubadhdhab, (Beirut: Dâr al-Fikr, 1990), Vol. XVI, 165., Shams al-Dîn al-Khaṭ̂ib al-Sharbînî, al-Iqnâ' fi Hịilli Alfâżi Abî Shujâ', (Beirut: Dâr al-Fikr, 1990), Vol. II, 77.

13 'Abdullah Ibnu Aḥmad Ibnu Qudâmah, al-Mughnî, (Beirut: Dâr al-Fikr, 1990), Vol. VII, 379 dan 'Abd al-Raḥmân Ibnu Ibrâhîm Bahâ' al-Dîn al-Maqdisî, al-Uddah Sharḥ al- 'Umdah, (Beirut: Dâr al-Kutub al-'Ilmiyyah, 2005), Vol. II, 8.

14 Aḥmad Ibnu Hạanbal, Musnad Aḥmad Ibnu Hanbal, (t.tp.: Muassasah al-Risâlah, 1999), No. Indeks 9603, Vol. II, 434., Muhammad Ibnu Ismâ’̂̀l al-Bukhârî, al-Jâmi' al-Ṣabîh, (Beirut: Dâr Ibnu Kathîr, 1987), No. Indeks 4843, 6769, 6567, bab al-Nikâh, Vol. V, 1574., Imam Muslim, al-Jâmi' al-Sahịh, (Beirut: Dâr al-Jayl, t.th.), ,No. Ideks 3538, Vol. IV, bab al-Nikâhh, 140.

15 Abû Daud, Sunan Abû Daud, (Beirut: Dâr al-Kitâb al-'Arabî, t.th.), Vol. II, No. Indeks 2100, 196., Muḥammad ibnu 'Îsâ al-Tirmidhî, Sunan al-Tirmidhî, (Beirut: Dâr Ihyâ’ al-Turâth, t.th.), Vol. III, No. Ideks 1108, 416., Imam Muslim, al-Jâmi’ al-Ṣaḥ̂h, (Beirut: Dâr al-Jayl, t.th.), Vol. IV, No. Ideks 3541, 141. Musnad Ahmad Ibnu Hanbal, (t.tp.: Muassasah alRisâlah, 1999), Vol. I, No. Indeks 1888, 1897, 2163, Mâlik Ibn Anas, al-Muwatța', (Beirut: Dâr al-Kutub al-'Alamiyyah, 2006), No. Indeks 1914, 427. 
walinya, sedangkan anak gadis diminta persetujuannya atas dirinya, dan persetujuannya adalah diamnya"

Menurut kelompok ini, stressing ḥadith adalah hukum bahwa janda lebih berhak atas walinya. Dengan adanya penyebutan dua objek hukum dalam satu hadîth yakni janda dan gadis, pasti terdapat hukum yang berbeda, maka gadis tidak memiliki otoritas apapun dalam pernikahan sehingga wali berhak menikahkan tanpa persetujuannya. ${ }^{16}$ Model pemaknaan semacam ini dalam istilah usûl al-fiqh disebut dengan mafhûm mukhâlafah atau dalîl al-kbitâb. ${ }^{17}$

Pemahaman ini kemudian menuntut adanya pemahaman di luar teks

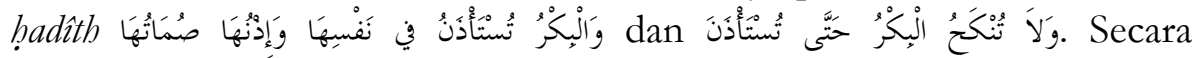
tekstual, makna yang seharusnya adalah bahwa gadis diminta persetujuannya dan salah satu bentuk persetujuannya adalah diam. Namun makna ini menjadi tidak berlaku setelah penetapan makna melalui model mafhûm mukhâlafah atau dalîl al-khitâb. Bahkan teks ḥadîth tersebut difahami bahwa diam merupakan bentuk persetujuan sehingga tanpa meminta persetujuan gadis memiliki makna yang sama dengan meminta persetujuannya. Oleh karenanya meminta persetujuan gadis dinilai fuqahâ' berhukum sunnah, ${ }^{18}$ bahkan al-Shâfî̀ mengistilahkannya

16 Abû 'Umar Yûsuf al-Namrî al-Qurtûbî, al-Istidbkâr al-Jâmi' li Madhâbib Funqabâ' al-Amșâr, (Beirut: Dâr al-Kutub al-'Tlmiyyah, 2000), Vol. V, 386., Muhammad Ibnu Idrîs al-Shâfi'̂̂, alUm, (Beirut: Dâr al-Ma'rifah, 1993), Vol. V, 18., Muhyi al-Dîn Yahyâ Ibnu Sharaf alNawâwî, al-majmû' Sharḥ al-Muhadhdhab, (Beirut: Dâr al-Fikr, 1990), Vol. XVI, 165., Shams al-Dîn al-Khatîib al-Sharbînî, al-Iqnâ' fi Hịilli Alfâż̧ Abî Shujâ', (Beirut: Dâr al-Fikr, 1990), Vol. II, 77., 'Abdullah Ibnu Aḥmad Ibnu Qudâmah, al-Mughnî, (Beirut: Dâr al-Fikr, 1990), Vol. VII, 379 dan 'Abd al-Raḥmân Ibnu Ibrâhîm Bahâ' al-Dîn al-Maqdisî, al-'Uddah Sharḥ alUmdah, (Beirut: Dâr al-Kutub al-'Ilmiyyah, 2005), Vol. II, 8., 'Abdullah Ibnu Ahmad Ibnu Qudâmah, al-Mughnî, (Beirut: Dâr al-Fikr, 1990), Vol. VII, 379 dan 'Abd al-Raḥmân Ibnu Ibrâhîm Bahâ’ al-Dîn al-Maqdisî, al-Uddah Sharḥ al-Umdah, (Beirut: Dâr al-Kutub al'Ilmiyyah, 2005), Vol. II, 8.

17 Mafhûm mukhâlafah adalah penetapan makna terbalik yang diambil dari dalil yang ditetapkan dalam nass (mantûq bih) pada makna yang tidak disebut dalam nass. (maskêt 'anbu). Lihat Mukhtar Yahya, Dasar-Dasar Pembinaan Hukum Fiqh Islam, (Bandung: Al-Ma'arif, 1986), 310.

18 Abû 'Umar Yûsuf Ibnu 'Abdillah Ibnu Muhammad Ibnu 'Abd al-Bar Ibnu 'Âșim alNamrî al-Qurțûbi, al-Kâfî fí Fiqh Abl al-Madinah, (Riyaḍ: Maktabat al-Riyâd al-Hadîthiyyah, 1980), Vol. II, 523-524., Abû al-Ḥasan 'Alî ibnu 'Abd al-Salâm al-Tasûlî, al-Babjah Sharḥ alTuhfah, (Beirut: Dâr al-Kutub al-'Ilmiyyah, 1998), Vol. I, 421., Muhyi al-Dîn Yahyâ Ibnu Sharaf al-Nawâwî, al-Majmû̀ Sharh al-Muhadhdhab, (Beirut: Dâr al-Fikr, 1990), Vol. XVI, 165., 'Abdullah Ibnu Aḥmad Ibnu Qudâmah, al-Mughnî, (Beirut: Dâr al-Fikr, 1990), Vol. VII, 379 dan 'Abd al-Raḥmân Ibnu Ibrâhîm Bahâ' al-Dîn al-Maqdisî, al-Uddah Sharḥ al-'Umdah, (Beirut: Dâr al-Kutub al-'Ilmiyyah, 2005), Vol. II, 8. 
dengan perintah yang sifatnya pilihan (amr ikhtiyâri) bukan fardu karena fungsinya untuk menggembirakan hati perempuan (istitâbah al-nafs). ${ }^{19}$

Hadith itu juga difahami bahwa diam hanya merupakan cara yang baik bagi gadis untuk mengungkapkan rasa sukanya pada laki-laki, bukan dengan perkataan. ${ }^{20}$ Namun demikian, al-Shâfi'î tetap menyarankan untuk melakukan musyawarah sebagai cara dan etika yang mulia sebagaimana perintah yang sifatnya tidak wajib dari Allah, ${ }^{21}$ yakni surat Ali 'Imrân (3) ayat 159:

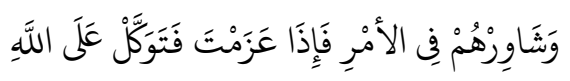

Artinya: “...dan bermusyawaratlah dengan mereka dalam urusan itu, kemudian apabila kamu telah membulatkean tekad, Maka bertawak.kallah kepada Allah."

Berbeda dengan kelompok fuqahâ' di atas, pendapat kedua meniadakan hak paksa wali dan menetapkan otoritas hak persetujuan anak gadis dewasa. Pendapat ini adalah pendapat fuqabâ' madhbab hanafiyyah, ${ }^{22}$ Ibnu Lubb dari madhhab mâlikîyah, ${ }^{23}$ serta sebagian madhhab hanâbilah, yakni salah satu pendapat Ahmad bin Hanbal, Abû Ja'far, AlZarkashî, Ibnu Taymiyah, ${ }^{24}$ dan Ibnu al-Qayyim al-Jawziyyah. ${ }^{25}$ Dasar yang digunakan pendapat ini adalah ḅadith Rasulullah SAW yang sama dengan kelompok pertama yang meniadakan persetujuan gadis dewasa namun dengan sudut pandang yang berbeda.

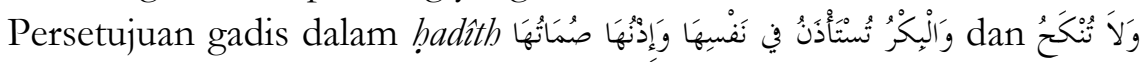
merupakan subtansi hadîth tersebut sehingga gadis dewasa

\footnotetext{
${ }^{19}$ Muhammad Ibnu Idrîs al-Shâfi'î, al-Um, (Beirut: Dâr al-Ma'rifah, 1993), Vol. V, 18.

20 Abû 'Umar Yûsuf al-Namrî al-Qurtûbî, al-Istidbkâr al-Jâmi' li Madhâhib Funqabâ' al-Amsâr, (Beirut: Dâr al-Kutub al-'Ilmiyyah, 2000), Vol. V, 390.

${ }^{21}$ Muhammad Ibnu Idrîs al-Shâfi'î, al-'Um, (Beirut: Dâr al-Ma'rifah, 1993), Vol. V, 18.

22 Muḥammad Ibnu al-Ḥasan al-Shaybânî, al-Hujjah 'alâ Abli al-Madînah, (Beirut: Dâr alKutub al-'Tlmiyyah, 1990), Vol. III, 126., Al-Sarkhasî, al-Mabsût li al-Sarkhasî, (Beirut: Dâr alFikr, 2000), Vol. IV, 180 dan lihat Vol. V, 3.

23 Abû al-Ḥasan 'Alî ibnu 'Abd al-Salâm al-Tasûlî, al-Babjah Sharḥ al-Tuhfah, (Beirut: Dâr alKutub al-'Ilmiyyah, 1998), Vol. I, 423.

24 'Alâ' al-Dîn Abû al-Ḥasan 'Alî al-Mardawî al-Dimashqî, al-Insâf Fî Ma'rifati al-Râjịh min alKhilâf 'alâ Madhhab al-Imâm Aḥmad Ibnu Hanbal, (Beirut: Dâr Ihyầ' al-Turâth al-‘Arabî, t.th.), Vol. 8, 42.

${ }^{25}$ Ibn Qayyim al-Jawziyyah, Zâd al-Ma'âd, (Mesir: Muștafâ al-Bâb al-Ḥalabî wa Awlâdih, 1970), Vol. IV, 3.
} 
juga harus diminta persetujuannya, sedangkan diamnya hanyalah salah satu bentuk persetujuan. ${ }^{26}$ Pemahaman ini didukung dengan ḥadîth lain:

عن عبد الله بن يزيد عن خنساء بنت خذام قالت: أنكحنى أبى وأنا كارهة وأنا بكر

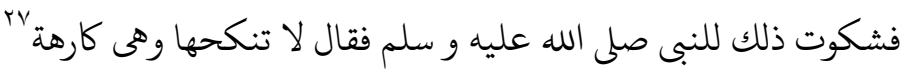

Artinya: Hadîth riwayat 'Abdullah Ibnu Yazîd, dari Khansâ' binti Khidâm al-Anșâriyyah yang berkata: "Aku dinikabkan ayabku dan aku tidak menyukainya sedangkan aku masih gadis. Lalu aku melapor pada Rasulullah SAW, dan Rasul bersabda: Jangan kau nikabkan anakmu sedangkan ia dalam keadaan tidak suka"

Al-Sarkhashi menambahkan ḥadîth:

عن عائشة قالت جاءت فتاة إلى رسول الله صلى الله عليه و سلم فقالت : يا رسول الله ان أبى

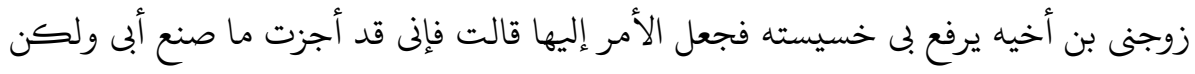

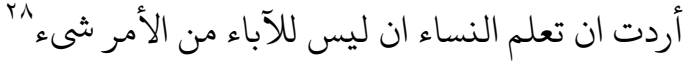

Artinya: Hadîth riwayat Aishah, ia berkata: Datanglah perempuan muda pada Rasulullah SAW dan berkata: "Ya Rasulullah sesunggubnya ayabku menikabkanku dengan anak saudaranya yang aku tidak memiliki rasa padanya. Lalu Rasulullab $S A W$ menyerabkan urusan ini sebagai hak perempuan tersebut. Lalu perempuan tersebut berkata: Saya memang telab memenubi apa yang diperbuat ayahku padaku, tetapi aku ingin memberitabukan pada semua perempuan babwa semua ayah tidak memiliki bak apapun terbadap anaknya (untuk menentukan pernikahan)"

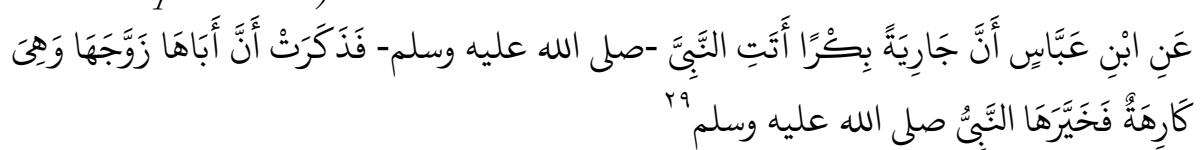

26 Al-Sarkhasî, al-Mabsût li al-Sarkhasî, (Beirut: Dâr al-Fikr, 2000), Vol. IV, 180., dan lihat Vol. V, 3., Abû al-Ḥasan 'Alî ibnu 'Abd al-Salâm al-Tasûlî, al-Bahjah Sharḥ al-Tuhfah, (Beirut: Dâr al-Kutub al-'Ilmiyyah, 1998), Vol. I, 423., 'Abd al-Raḥmân Ibnu Ibrâhîm Bahâ' al-Dîn al-Maqdisî, al-Uddah Sharḅ al-'Umdah, (Beirut: Dâr al-Kutub al-'Ilmiyyah, 2005), Vol. II, 8.

27 Abû Muhammad al-Dârimî, Sunan al-Dârimî, (Beirut: Dâr al-Kitâb al-'Arabî, t.th.), No. Indeks 2192, bab al-Nikâh, Vol. II, 187., Ahmad Ibnu Shu'ayb al-Nasâ'î, Sunan al-Nasầ̂ alKubrâ, (Beirut: Dâr al-Kutub al-'Ilmiyyah, 1991), No. Indeks 5382, Vol. III, 282. Selain hadîth di atas, al-Nas'î juga meriwayatkan hadîth dengan struktur kata al-tahayyib. Namun hadîth ini struktur matannya menunjukkan pengakuan khansấ bukan informasi dari orang lain atas kejadian al-khansấ.

28 Aḥmad Ibnu Ḥanbal, Musnad Ạ̣mad Ibnu Ḥanbal, (t.tp.: Muassasah al-Risâlah, 1999), No. Indeks 25087, Vol. VI, 136. 
Artinya: Riwayat dari Ibnu 'Abbâs babwasannya seorang perempuan gadis datang pada Rasulullab SAW lalu menceritakan bahwa ayahnya menikabkannya tetapi ia tidak menyukainya. Lalu rasulullab $S A W$ memberikan hak pilih pada perempuan untuk meneruskan atau menggagalkan pernikahannya"

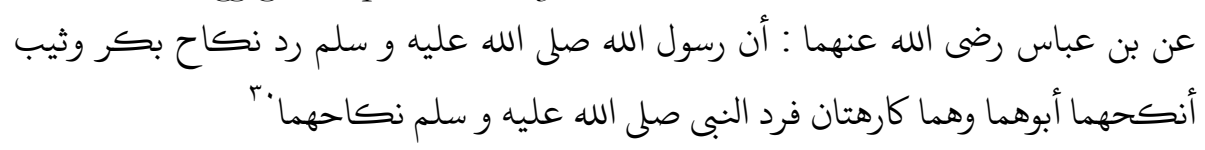

Artinya: Riwayat dari Ibnu 'Abbâs babwasannya Rasulullab SAW membatalkean pernikahan gadis dan janda yang dinikabkan ayahnya, sedangkan mereka tidak suka. Lalu rasulullah SAW membatalkan pernikahannya"

Hadîth tentang pembatalan pernikahan yang menggunakan redaksi

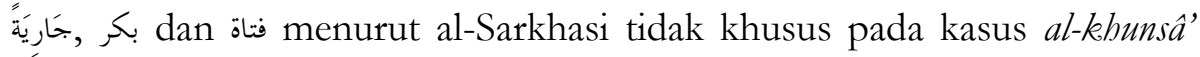
(yang saat itu janda), melainkan menunjukkan kejadian lain dengan pelaku seorang gadis. ${ }^{31}$ Mengenai status ḥadîth, Shu'ayb al-Arnût selaku muhaqqiq dalam catatan kaki kitab Musnad Ahmad Ibnu Hanbal mengutip pendapat Ibnu al-Qațân dan al-Zayla'î bahwa ḥadith tersebut sahı̂h yang didukung dengan hadîth sabîh lainnya yang diriwayatkan perawi yang sama, yakni Ibnu 'Abbâs. ${ }^{32}$ Bahkan dalam salah satu ḥadîth di atas,

${ }^{29}$ Abû Daud, Sunan Abû Daud, (Beirut: Dâr al-Kitâb al-'Arabî, t.th.), No. Indeks 2198, Vol. II, 195., Abû Daud menyatakan bahwa sekalipun hadîth ini mursal tetapi telah banyak dikenal masyarakat., Ibnu yazîd al-Qazwînî, Sunan Ibnu Mâjah, (Beirut: Dâr al-Fikr, t.th.), No. Indeks 1875, Vol. I, 603., Aḥmad Ibnu Hanbal, Musnad Aḅmad Ibnu Hanbal, (t.tp.: Muassasah alRisâlah, 1999), No. Indek 2469, Vol. I, 273., Dalam catatan kaki kitab ini yang ditulis Shu'aib al-Arnût menyatakan bahwa hadîth ini sahîh secara jelas terlebih dalam riwayat Ibnu 'Abbâs أن رسول الله صلى الله عليه و سلم رد نكاح بكر وثيب أنكحهما أبوهما وهما كارهتان فرد الني صلى الله عليه و سلم lainnya نكاحهم dinyatakan sahîh. Aḥmad Ibnu al-Khusayn al-Bayhaqî, Sunan al-Bayhaqî al-Kubrâ, (Mekkah: Maktabat Dâr al-Bâz, 1994), No. Indeks 13447, Vol. VI, 177. Al-Bayhaqî menyatakan bahwa hadîth ini khata' karena terdapat perawi Jarîr Ibnu Khâzîm yang kemungkinan kecil bertemu Ayyûb al-Sikhtiyânî.

30 Ahmad Ibnu al-Khusayn al-Bayhaqî, Sunan al-Bayhaqî al-Kubrâ, (Mekkah: Maktabat Dâr alBâz, 1994), No. Indeks 13449, Vol. VI, 177. Al-Bayhaqî menyatakan bahwa hadîth ini khata' karena hadîth yang diriwayatkan Ibnu 'Abbâs dalam No. Indeks 13447 adalah kbata'., 'Alî ibnu 'Umar al-Dâruquṭnî, Sunan al-Dâruqutnî, (Beirut: Dâr al-Ma'rifah, 1966), No. Indeks 53, Vol. III, 234. Al-Dâruqițî menyatakan bahwa hadîth ini lemah, tetapi hadîth riwayat lain yang diungkap Ibnu 'Abbâs adalah mursal yang saḥ̂h menjadikan hadìth ini kuat.

${ }^{31}$ Al-Sarkhasî, al-Mabsût li al-Sarkhasî, (Beirut: Dâr al-Fikr, 2000), Vol. V, 3.

32 Lihat Aḥmad Ibnu Hanbal, Musnad Aḥmad Ibnu Hanbal, (t.tp.: Muassasah al-Risâlah, 1999), No. Indek 3440, Vol. I, 364. 
secara tegas dinyatakan bahwa al-Khunsâ' saat itu berstatus gadis, bukan janda.

Adapun tentang hukum gadis yang masih kecil (al-biker al-șaghirah), fuqhâ' sepakat memperbolehkan pemaksaan nikah terhadapnya tanpa menghiraukan persetujuannya. ${ }^{33}$ Dasar yang digunakan sama dengan hukum gadis dewasa. Sekalipun sepakat, namun fuqahâ' berbeda terkait argumentasinya. Fuqahâ' hanafiyyah menyatakan alasannya adalah karena anak kecil bukanlah subjek hukum. ${ }^{34}$ Dengan demikian, sifat kana-kanak (sighâr) dinilai meniadakan kecakapan hukum, sehingga setiap yang memiliki sifat kecil (sighâr) menjadikan illat diperbolehkannya memaksakan pernikahan oleh wali, termasuk janda kecil (al-thayyib alsaghîrah). ${ }^{35}$ Ibnu Lubb dalam madhhab mâlikîyah juga senada dengan hanafiyyah. ${ }^{36}$

Sedangkan menurut fuqahâ' mâlikîyah di antaranya Abû 'Umar Yûsuf Ibnu 'Abdillah Ibnu Muhammad Ibnu 'Abd al-Bar Ibnu 'Âṣim al-Namrî al-Qurtûbî̀, Abû al-Ḥasan 'Alî ibnu 'Abd al-Salâm al-Tasûlî, fuqahâ' madhhab shâfi'iyyah diantaranya al-Shâfi'î, al-Nawâwî, al-Khatîib alSharbînî, Mûsâ al-Hijâwî, fuqahâ' madhhab ḥanâbilah di antaranya Ibnu Qudâmah dan Bahâ' al-Dîn al-Maqdisî, semuanya menyatakan bahwa

\footnotetext{
33 Al-Sarkhasî, al-Mabsût li al-Sarkhasî, (Beirut: Dâr al-Fikr, 2000), Vol. V, 4., Ibnu Nujaym, al-Baḅr al-Râ'iq Sharh Kanzu al-Daqẩiq, (Beirut: Dâr al-Ma'rifah, t.th), Vol. III, 117., Abû 'Umar Yûsuf Ibnu 'Abdillah Ibnu Muhammad Ibnu 'Abd al-Bar Ibnu 'Âșim al-Namrî alQurțîbi, al-Kâfî fî Fiqh Abl al-Madînah, (Riyaḍ: Maktabat al-Riyậ al-Hadîthiyyah, 1980), Vol. II, 523-524., Abû 'Umar Yûsuf al-Namrî al-Qurțûbî, al-Istidbkâr al-Jâmi' li Madhâhib Funqahâ' al-Amsâr, (Beirut: Dâr al-Kutub al-'Ilmiyyah, 2000), Vol. V, 389., Abû al-Hasan 'Alî ibnu 'Abd al-Salâm al-Tasûlî, al-Bahjah Sharh al-Tuhfah, (Beirut: Dâr al-Kutub al-'Ilmiyyah, 1998), Vol. I, 421., Abû al-Walîd Muhammad ibnu Aḥmad bin Rushd al-Qurțûbî al-Andalûsî, Bidâyat al-Mujtahid wa Nihâyat al-Muqtasid, (Bierut: Dâr al-Fikr, t.th.), Vol. II, 4., Muhammad Ibnu Idrîs al-Shâfî̂, al-Um, (Beirut: Dâr al-Ma'rifah, 1993), Vol. V, hal. 18., Muhyi al-Dîn Yahyâ Ibnu Sharaf al-Nawâwî, al-Majmû' Sharḥ al-Muhadhdhab, (Beirut: Dâr al-Fikr, 1990), Vol. XVI, 165., Shams al-Dîn al-Khatîib al-Sharbînî, al-Iqnâ' fi Hịilli Alfâżi Abî Shujâ’, (Beirut: Dâr al-Fikr, 1990), Vol. II, 77., 'Abdullah Ibnu Aḥmad Ibnu Qudâmah, al-Mughnî, (Beirut: Dâr al-Fikr, 1990), Vol. VII, 379.

${ }^{34}$ Kamâl al-Dîn Muhammad Ibnu 'Abd al-Wâhịd al-Sîwâsî, Sharḥ Fatḥ al-Qadîr, (Beirut: Dâr al-Fikr, t.th.), Vol. III, 261.

35 Ibnu Nujaym, al-Baḥr al-Râiq Sharḥ Kanæu al-Daqâiq, (Beirut: Dâr al-Ma'rifah, t.th), Vol. III, 117.

36 'Alâ' al-Dîn Abû al-Hasan 'Alî al-Mardawî al-Dimashqî, al-Insâf Fî Márifati al-Râjịh min alKhilâf 'alâ Madhhab al-Imâm Aḥmad Ibnu Hanbal, (Beirut: Dâr Ihyầ' al-Turâth al-'Arabî, t.th.), Vol. 8, 42., 'Alâ' al-Dîn Abû al-Ḥasan 'Alî al-Mardawî al-Dimashqî̀, al-Insâf Fî̀ Ma'rifati alRâjị̆ min al-Khilâf 'alâ Madhhab al-Imâm Aḅmad Ibnu Hanbal, (Beirut: Dâr Ihyyâ’ al-Turâth al'Arabî, t.th.), Vol. 8, 43.
} 
gadis kecil sama halnya dengan gadis dewasa karena keumuman teks hadîth yang menggunakan kata al-bikr, sehingga seluruh gadis baik kecil maupun dewasa berhukum sama, yakni tidak memiliki hak persetujuan, sehingga walinya berhak memaksa tanpa persetujuannya. ${ }^{37}$

Dengan demikian, illat diperbolehkannya wali memaksakan pernikahan pada perempuan di bawah perwaliannya menurut hanafiyyah adalah karena sifat kanak-kanak (sighar) sehingga gadis atau janda yang telah dewasa tidak dapat dipaksa menikah oleh wali. Sedangkan menurut madhhab lainnya adalah karena sifat perawan (bikr) sehingga janda yang dewasa ataupun masih kanak-kanak tidak dapat dipaksa menikah oleh walinya.

Sekalipun seluruh madhhab memberikan peluang bagi wali untuk memaksakan pernikahan pada anaknya dengan berbagai argumentasi, namun semua madhhab memberikan batasan tentang pihak yang boleh memaksa. Menurut fuqahâ' madhhab mâlikîyah, shâfi'iyyah dan ḥanâbilah yang berhak memaksa adalah ayah kandung, ${ }^{38}$ karena selain ayah kurang memiliki rasa sayang (qâsir al-shafaqah). Shâfi'iyyah menambahkan kakek sebagai pihak yang boleh memaksa karena kakek dinilai memiliki sifat sebagaiaman ayah. Dan anak kecil yang dinikahkan oleh ayahnya tidak memiliki hak khiyâr ketika bâligh sebagaimana yang berlaku di daerah Hijâz. ${ }^{39}$ Sedangkan menurut hanafíyyah, semua wali baik ayah maupun selain ayah boleh memaksakan pernikahan pada anaknya. Hanya saja jika wali tersebut adalah ayah, maka sang anak tidak memiliki hak khiyâr

\footnotetext{
37 Abû 'Umar Yûsuf Ibnu 'Abdillah Ibnu Muhammad Ibnu 'Abd al-Bar Ibnu 'Âșim alNamrî al-Qurtûbi, al-Kâfî fì Fiqh Abl al-Madînah, (Riyaḍ: Maktabat al-Riyậ al-Hadîthiyyah, 1980), Vol. II, 523-524., Abû al-Ḥasan 'Alî ibnu 'Abd al-Salâm al-Tasûlî, al-Babjah Sharḥ alTuhfah, (Beirut: Dâr al-Kutub al-'Ilmiyyah, 1998), Vol. I, 421., Muḥammad Ibnu Idrîs alShâfi'î, al-'Um, (Beirut: Dâr al-Ma'rifah, 1993), Vol. V, 18., Muhyi al-Dîn Yahyâa Ibnu Sharaf al-Nawâwî, al-Majmû' Sharḥ al-Muhadhdhab, (Beirut: Dâr al-Fikr, 1990), Vol. XVI, 165. Shams al-Dîn al-Khaṭîb al-Sharbînî, al-Iqnâ' fi Hịlli Alfâż̧i Abî Shujầ, (Beirut: Dâr al-Fikr, 1990), Vol. II, 77., 'Abdullah Ibnu Aḥmad Ibnu Qudâmah, al-Mughnî, (Beirut: Dâr al-Fikr, 1990), Vol. VII, 379 dan 'Abd al-Raḥmân Ibnu Ibrâhîm Bahâ' al-Dîn al-Maqdisî, al- 'Uddah Sharh al-Umdah, (Beirut: Dâr al-Kutub al-'Ilmiyyah, 2005), Vol. II, 8.

38 Abû 'Umar Yûsuf al-Namrî al-Qurțîbî, al-Istidhkâr al-Jâmi' li Madhâhib Funqahâ' al-Amsâr, (Beirut: Dâr al-Kutub al-'Ilmiyyah, 2000), Vol. V, 389., Muhyi al-Dîn Yahyâ Ibnu Sharaf alNawâwî, al-Majmû' Sharḥ al-Muhadhdhab, (Beirut: Dâr al-Fikr, 1990), Vol. XVI, 165. , 'Abdullah Ibnu Aḥmad Ibnu Qudâmah, al-Mughnî, (Beirut: Dâr al-Fikr, 1990), Vol. VII, 379. 39 Abû 'Umar Yûsuf al-Namrî al-Qurtûbî, al-Istidbkâr al-jâmi' li Madhâbib Funqahâ' al-Amsâr, (Beirut: Dâr al-Kutub al-'Ilmiyyah, 2000), Vol. V, 401., Abû 'Umar Yûsuf al-Namrî alQurțîîi, al-Istidbkâr al-Jâmi' li Madbâbib Funqahâ' al-Amsâr, (Beirut: Dâr al-Kutub al'Ilmiyyah, 2000), Vol. V, 389., Muhyyi al-Dîn Yahyâ Ibnu Sharaf al-Nawâwî, al-Majmû' Sharḥ al-Muhadhdhab, (Beirut: Dâr al-Fikr, 1990), Vol. XVI, 165.
} 
ketika bâligh, sedangkan jika wali bukan ayah maka anak memiliki hak khiyâr ketika bâligh. ${ }^{40}$

Selain terdapat batasan tentang siapa yang berhak memaksa, fuqabâ juga merumuskan persyaratan pelaksanaan hak ijbâr. Al-Khatîib alSharbînî dan Mûsâ al-Hijâwi dalam madhhab shâfíiyyah merumuskan persyaratan: (1) secara lahiriyyah tidak terdapati persmusuhan antara anak dan wali, (2) wali harus menikahkan dengan calon suami yang setara (kufu), (3) mahar yang diterima minimal sesuai dengan standar minimal mahar yang berlaku di masyarakat (mahar mithi), (4) mahar berupa mata uang atau perhiasan yang berlaku di negara setempat, (5) calon suami bukan tergolong orang tidak mampu membayar mahar, (6) wali tidak boleh menikahkan dengan orang yang akan menyengsarakan ketika mu'âsharah, seperti terlalu tua atau buta. ${ }^{4}$

Sedangkan Shaykh Abû Bakar Muhammad Shaṭ̂a mensyaratkan bahwa (1) antara anak perempuannya tersebut dengan wali mujbîr-nya tidak terjadi permusuhan yang diperlihatkan secara lahir ('adâwah zâhirah), (2) antara anak perempuannya tersebut dengan calon suami yang dipilih wali mujbîr terjadi permusuhan ('adâwah) walaupun permusuhan yang tidak ditampakkan secara lahir, (3) calon suami pilihan wali mujbîr harus se-kufu' (sepadan), dan (4) calon suami pilihan wali mujbîr mampu membayar mahar mithil. Jika syarat tersebut tidak terpenuhi, maka pernikahannya batal. $^{42}$

Adapun menurut hanâbilah, syaratnya adalah bahwa laki-laki yang dinikahkan dengan anaknya tersebut harus se-kufu' sebagaimana diungkap al-Mardawî dan Ibnu Taymiyyah. ${ }^{43}$ Dengan adanya persyaratanpersyaratn itu, hak paksa wali mujbir bukan tidak terbatas, tetapi tetap dibatasi dengan hak-hak yang dimiliki oleh anak perempuannya.

\section{Konsep Hukum Wali Aḍal sebagai Perlindungan Hak Perempuan}

Pembahasan wali mujbir tidak bisa dilepaskan dengan pembahasan wali adal sebab syarat-syarat wali mujbir terlihat sebagai antonim dari kriteria wali adal. Wali adal merupakan istilah dari seorang wali yang

\footnotetext{
40 Al-Sarkhasî, al-Mabsût li al-Sarkhasî, (Beirut: Dâr al-Fikr, 2000), Vol. V, 388-389.

${ }^{41}$ Shams al-Dîn al-Khațîb al-Sharbînî, al-Iqnâ' fi Hịilli Alfâżi Abî Shujâ', (Beirut: Dâr al-Fikr, 1990), Vol. II, 77.

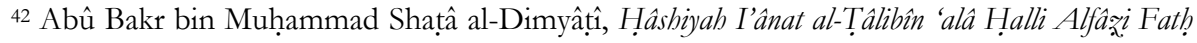
al-Mu'în, (Beirut: Dâr Ibnu 'Aș̣âșaha, 2005), Vol. III, 308-309.

43 'Alâ' al-Dîn Abû al-Ḥasan 'Alî al-Mardawî al-Dimashqî̀, al-Insâf Fî Ma'rifati al-Râjịh min alKhilâf 'alâ Madhhab al-Imâm Aḥmad Ibnu Hanbal, (Beirut: Dâr Ihyyâ' al-Turâth al-'Arabî, t.th.), Vol. 8, 42.
} 
dinyatakan tidak berhak lagi untuk menikahkan anaknya atau perempuan yang menjadi perwaliannya dengan beberapa syarat atau kondisi tertentu sehingga perwaliannya pindah kepada hakim. Dijelaskan oleh Abdurrahman al-Jazîrî dalam al-Fiqh 'alâ Madhâhib al-Arba'ah bahwa wali dikatakan adal jika wali menolak pernikahan anak perempuannya dengan calon yang se-kufu' walaupun tanpa mahar mithil. Maka perwalian perempuan tersebut dapat berpindah kepada hakim. ${ }^{44}$ Begitu juga Syamsuddin Muhammad bin Ahmad al-Khaṭ̂b al-Shirbînî dalam Mughni al-Muhtâj menjelaskan bahwa wali dikatakan aḍl itu jika anak perempuannya yang rashîdah (memiliki kecakapan berfikir) ataupun safîhah (tidak memiliki kecakapan berfikir) meminta untuk dinikahkan dengan calon yang se-kufu' dan wali tidak berkenan menikahkannya. ${ }^{45}$ Menurut Zainuddin Abû Yahyâ Zakariyâ al-Anşârî dalam karyanya alGhurar al-Bahîyah bi Sharh al-Bahjah al-Wardîyah menyatakan bahwa wali yang tidak berkenan menikahkan anaknya adalah wali adal dan hukumnya dosa sebab adanya perintah untuk tidak menolak pernikahan anaknya. ${ }^{46}$ Sebagaimana firman Allah dalam surat al-Baqarah ayat 232:
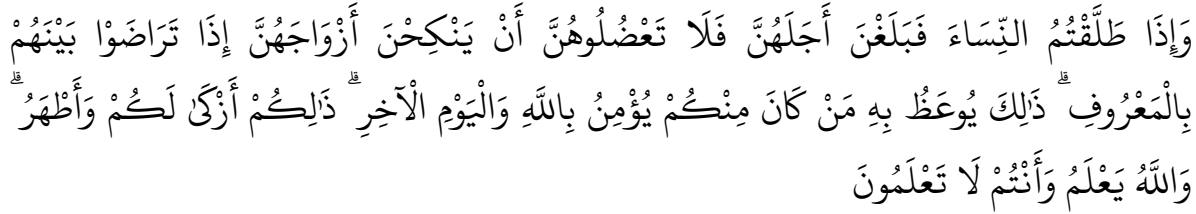

Artinya: "Apabila kamu mentalak isteri-isterimu, lalu habis masa iddahnya, maka janganlah kamu (para wali) menghalangi mereka kawin lagi dengan bakal suaminya, apabila telah terdapat kerelaan di antara mereka dengan cara yang ma'ruf. Itulah yang dinasehatkan kepada orang-orang yang beriman di antara kamu kepada Allah dan hari kemudian. Itu lebih baik bagimu dan lebih suci. Allah mengetahui, sedang kamu tidak mengetabui."

Pendapat Imam al-Shâfi'î yang diutarakan oleh Imam al-Nawâwî dalam al-Majmû' menyatakan bahwa hak perwalian dalam pernikahan adalah hak dari para wali yang berarti harus ditunaikan. Oleh karenanya, ketika para wali tidak berkenan menunaikan haknya (kewajibannya), maka hakim harus memerintahkannya. Jika wali tetap tidak berkenan

\footnotetext{
44 Abdurraḥman al-Jazîrî, al-Fiqh 'alâ Madhâhib al-Arba'ah, (Beirut: Dâr al-Kutub al-Ilmîyah, 1971), Vol. IV, 41.

45 Shamsuddin Muhammad bin Aḥmad al-Khaṭîb al-Shirbînî, Mughni al-Muḥtâj, (t.tp.: Maktaba Shamelah, t.th.), Vol. III, $19 \dot{9}$.

46 Zainuddin Abû Yahyâ Zakariyâ al-Ansârî, al-Ghurar al-Babîyah bi Sharḥ al-Babjah alWardîyah Vol. VII (Beirut: Dar Kutub Ilmiyah, 1997), 334.
} 
menunaikan haknya maka hakim mengambil hak tersebut secara paksa sebagaimana pemenuhan hak dalam masalah hutang piutang. ${ }^{47}$ Sama halnya dengan Shaykh Syamsuddin Muhammad bin Ahmad al-Khatîb alShirbînî dalam karyanya al-iqnâ' fî hall alfaz abî shujâ' menyatakan bahwa hak perwalian dalam pernikahan adalah hak dari para wali yang berarti harus ditunaikan. Oleh karenanya, ketika para wali tidak berkenan menunaikan haknya (kewajibannya), maka dinilai sebagai wali adal dan perwaliannya berpindah kepada hakim. ${ }^{48}$

Keengganan wali untuk menikahkan anaknya atau orang yang di bawah perwaliannya menjadikan kosongnya posisi wali. Hal demikian menjadi berat bagi perempuan yang telah jelas-jelas memiliki calon pasangan yang siap menjadi penuntunnya. Kondisi demikian tergolong darurat atau mashaqqah sehingga butuh ketentuan hukum yang meringankan bagi wanita tersebut, yaitu pindahnya hak perwalian kepada hakim. Perpindahan hak perwalian dari wali nasab kepada wali hakim telah dijelaskan dalam hadits:

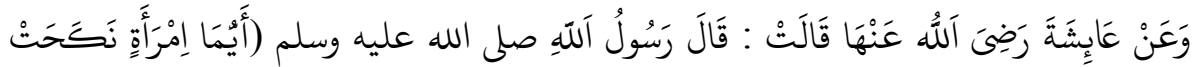

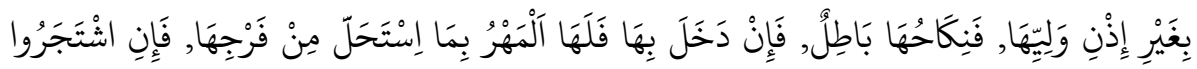

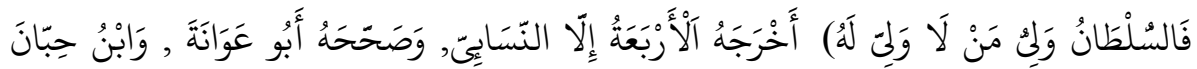

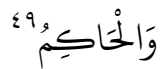

Artinya: Dari 'Aisyah radliyallâhu 'anha, dia berkata, Rasulullah Shallallâhu 'alaihi Wa Sallam bersabda: "Siapa saja wanita yang menikah tanpa idzin walinya, maka pernikahannya batil; jika dia (suami) sudah berbubungan badan dengannya, maka dia berbak mendapatkan mahar sebagai imbalan dari dihalalkannya farajnya; dan jika mereka berselisih, maka sultan adalab wali bagi orang yang tidak. memiliki wali."

Hadits tersebut berada dalam riwayat Imam Aḥmad, al-Shâfi'î, Abû Daud, al-Turmudhî, Ibn Mâjah, ad-Daruquthniy, al-Hâkim dan alBaihaqiy serta selain mereka dari jalur yang banyak sekali melalui Ibn Jurayj dari Sulaymân bin Mûsâ dari al-Zuhrî dari 'Urwah dari 'Aishah.

\footnotetext{
${ }^{47}$ Muhyyi al-Dîn Yahyâ Ibnu Sharaf al-Nawâwî, al-majmû̉ Sharḥ al-Muhadhdhab, (Beirut: Dâr al-Fikr, 1990), Vol. XVII, 322.

48 Shams al-Dîn al-Khațîb al-Sharbînî, al-Iqnâ' fi Hịlli Alfàżi Abî Shujâ' Vol. II, (Beirut: Dâr alFikr, 1990), 413.

49 Aḥmad bin Ali bin Ḥajar al-Asqalâni, Bulugh al-Marâm, (Almanshurah: Dâr al-Manarah, 2003), 365.
} 
Para periwayat dalam mata rantai periwayatan tersebut semuanya thiqqah menurut Imam Muslim. Status hadits ini menurut al-Hâkim sahih. ${ }^{50}$

Selanjutnya, dari berbagai literatur yang ada, wali dapat dikatakan adal jika memiliki beberapa kriteria tertentu. Kriteria tersebut dapat dirumuskan sebagai berikut:

Pertama, adanya penolakan dari wali untuk menikahkan anaknya atau perempuan yang di bawah perwaliannya. Kriteria pertama ini merupakan kriteria yang pasti ada sebab jika tidak ada penolakan maka wali tidak dinilai sebagai adal. Para ulama' juga dalam memberikan kriteria adal wali selalu menyertakan kata mana'a (penolakan) dan derifasinya. Di antaranya dalam pernyataan Abdurrahman al-Jazirî, ${ }^{51}$ Syamsuddin Muhammad bin Aḥmad al-Khatîib al-Shirbînî, ${ }^{52}$ dan Abdullah bin Hịâzi bin Ibrâhim alSharqâwi. ${ }^{53}$

Kedua, anak perempuannya atau perempuan yang di bawah perwaliannya yang mengajukan pernikahan telah bâligh dan berakal. Syekh Sulaymân bin Muhammad bin Umar al-Bujayramî menyatakan bahwa jika perinkahan diajukan oleh anak perempuan wali yang telah bâligh dan berakal dapat menyebabkan wali dinyatakan adal jika ada penolakan dari wali. ${ }^{54}$ Anak perempuan tersebut bukan hanya perempuan yang bukan anak atau cucu kandungnya yang di bawah perwaliannya, melainkan juga mujbarah (anak atau cucu perempuan yang boleh untuk dipaksa oleh wali mujbir). Hal ini dapat dilihat dalam pernyataan Syamsuddin Muḥammad bin Aḥmad al-Khaṭ̂ib al-Shirbînî yang menggunakan kata mujbarah (anak atau cucu perempuan yang boleh dipaksa wali mujbîr) ketika menjelaskan wali adal. ${ }^{55}$ Oleh karenanya, jika terdapat pemahaman bahwa wali aḍal hanyalah teruntuk wali selain wali mujbîr adalah pemahaman yang keliru karena pernyataan Syamsuddin Muhammad bin Aḥmad al-Khaṭîb al-Shirbînî tersebut telah jelas menyatakan wali mujbir juga dapat dikategorikan adal.

\footnotetext{
50 Aḥmad bin Ali bin Hajar al-Asqalâni, Bulugh al-Marâm, 365.

51 Abdurraḥman al-Jazîrî, al-Fiqh 'alâ Madhâhib al-Arba'ah, (Beirut: Dâr al-Kutub al-Ilmîyah, 1971), Vol. IV, 41.

52 Shamsuddin Muhammad bin Aḥmad al-Khaṭîb al-Shirbînî, Mughni al-Mụ̣tâj, (t.tp.: Maktaba Shamelah, t.th.), Vol. III, 199.

${ }^{53}$ Abdullah bin Hijâzi bin Ibrâhim al-Sharqâwî, Hâashiyah al-Sharqâwî̀, (t.tp.: Maktabah Shamelah, t.th.), Vol. II, 230.

${ }^{54}$ Sulaymân bin Muhammad bin 'Umar al-Bujayramî, Al-Bujayramî 'ala al-Khatî̉, (t.tp.: Maktabah Shamelah, t.th.), Vol. III, 230.

55 Shamsuddin Muh"ammad bin Aḥmad al-Khaṭ̂ib al-Shirbînî, Mughni al-Muḥtâj, (t.tp.: Maktaba Shamelah, t.th.), Vol. III, 199.
} 
Ketiga, calon yang diajukan anaknya atau perempuan yang di bawah perwaliannya adalah se-kufu' (sepadan). Ulama' sepakat tentang kufu' (sepadan) sebagai hal yang menetukan tentang adal dan tidaknya wali. Artinya, bahwa wali yang menolak pernikahan karena calon yang diajukan anaknya atau perempuan yang berada dalam perwaliannya tidak se-kufu' maka wali tidak dianggap adal. Namun jika sebaliknya, calon anaknya atau wanita di bawah perwaliannya tersebut adalah se-kufu', maka penolakan wali berakibat pada adal-nya wali. Sebagaimana pendapat Sheykh Abû Bakar Muhammad Shatâa yang menyatakan bahwa jika anak perempuannya menentukan kriteria kufu' sementara sang ayah atau kakek memiliki kriteria kufu' yang berbeda, maka ayah atau kakek berhak untuk menolak. Dan penolaknnya tidak menjadikan wali tersebut adal, bahkan seandainya calon dari sang ayah tidak lebih baik (tidak lebih kufu) dari calon yang diajukan sang anak pun wali tetap tidak dianggap adal karena wali bisa menilai yang lebih maslahah. ${ }^{56}$ Pendapat ini senada dengan pendapat Shaykh Muhyiddin Abû Zakariyya Yahyâ bin Sharaf al-Nawâwî atau yang dikenal dengan Imam al-Nawâwî dalam karyanya rawdat altâlibîn. ${ }^{57}$ Sayyid Sâbiq juga mendukung pendapat ini. ${ }^{58}$

Sementara Syaykh Syamsuddin Muhammad bin Ahmad al-Khațîb alShirbînî menyatakan bahwa jika anak perempuannya menentukan kriteria kufu' sementara sang ayah atau kakek memiliki kriteria kufu' yang berbeda, maka menurut pendapat yang asạ. (yang diunggulkan) bahwa ayah atau kakek berhak untuk menolak mengingat ayah atau kakek dinilai sempurna dalam melihat kondisi anaknya. Artinya dalam kondisi demikian wali tidak dikategorikan adal. Dalam pandangan Imam al-Subkî, kondisi demikian wali termasuk ayah atau kakek harus menyetujui permohonan anaknya untuk menjaga kehormatan sang anak. Pendapat Imâm a-Subkî ini menurut Syaykh Syamsuddin Muhammad bin Aḥmad al-Khațîb al-Shirbînî dianggap sebagai pendapat mu'tabar yang sesuai dengan pendapat Imam al-Nawawî dan Imam al-Rafîî karena asal dari hukum menikahkan anaknya tergantung pada persetujuan sang anak tersebut. $^{59}$

\footnotetext{
56 Abû Bakr bin Muhammad Shatâ al-Dimyâtî, Hậshiyah I'ânat al-Tâalibîn 'alâ Halli Alfầzi Fath al-Mu'în, (Beirut: Dâr Ibnu 'Asssâșah, 2005), Vol. III, 218.

${ }^{57}$ Muhyiddin Abû Zakariyya Yahya bin Syaraf al-Nawawi, Rawdat al-Ṭalibîn, (t.tp.: Maktabah Shamelah, t.th.), Vol. VI, 53.

${ }^{58}$ Sayyid Sâbiq, Fiqh al-Sunnah, (Beirut: Dar al-Fikr, 1992), Vol. VII, 121.

59 Shamsuddin Muhammad bin Aḥmad al-Khaṭîb al-Shirbînî, Mughni al-Muḥtâj, (t.tp.: Maktaba Shamelah, t.th.), Vol. III, 199.
} 
Dengan demikian dapat disimpulkan bahwa jika terjadi pertentangan antara wali (mujbir) dengan anak perempuannya maka sebagian ulama' menyatakan yang dimenangkan adalah pilihan sang ayah sehingga penolakannya terhadap pernikahan sang anak dengan calon pilihan sang anak tidaklah menjadikan wali tersebut adal. Sebagian lainnya menyatakan bahwa yang dimenangkan adalah pilihan sang anak sehingga penolakan wali terhadap pernikahan sang anak menjadikan wali tersebut adal. Walaupun berbeda, namun ulama' tetap sepakat bahwa kufu' adalah hal yang harus dipenuhi dalam pernikahan. Bahkan Sayyid 'Abdul al-Raḥmân bin Muhammad bin Husayn bin 'Umar Bâ 'Alawî al-Ḥadramî dalam Bughyat al-Mustarshidîn mengatakan bahwa wali mujbîr yang menikahkan anaknya secara paksa dengan laki-laki yang fâsiq (tidak sekufu'), maka pernikahannya dinyatakan tidak sah. ${ }^{60}$

Keempat, calon yang diajukan anaknya atau perempuan yang di bawah perwaliannya tidak harus mampu membayar mahar mithil. Shaykh Syamsuddin Muhammad bin Aḥmad al-Khatîb al-Shirbînî, Syaikh Abdullah bin Hijâzi bin Ibrâhim al-Sharqâwî dan Abdurrahman al-Jazîrî menyatakan bahwa wali tidak boleh menolak pernikahan anaknya dengan calon suami pilihan anaknya yang tidak tidak mampu membayar mahar mithil secara penuh selama anaknya tersebut rela dengan kondisi calon suami tersebut karena mahar adalah hak anaknya (perempuan). ${ }^{61}$ Dengan kata lain, wali tetap dikatakan adal jika menolak pernikahan anaknya dengan calon pilihan anaknya walaupun calon tersebut tidak mampu membayar mahar mithil.

Kondisi ini berbalik ketika yang mengajukan pernikahan adalah sang wali. Maka harus disyaratkan adanya kemampuan membayar mahar mithil bagi calon dari wali tersebut. Sebagaimana pendapat Shaykh Abû Bakar Muhammad Shațâ bahwa jika wali mujbîr menikahkan anaknya dengan calon pilihan wali tersebut di mana sang calon tidak sekufu' atau tidak mampu membayar mahar mithil maka pernikahannya tidak sah. Pendapat ini adalah pendapat Imam al-Nawâwî dan Imam al-Ramlî walaupun ada

\footnotetext{
${ }^{60}$ Abdur Raḥmân bin Muḥammad bin Ḥusayn bin 'Umar Bâ 'Alawî al-Haḍramî , Bughyat alMustarshidin (t.tp.: Maktabah Shamelah, t.th.), 209.

61 Shamsuddin Muhammad bin Aḥmad al-Khaṭîb al-Shirbînî, Mughni al-Mụ̣tâj, (t.tp.: Maktaba Shamelah, t.th.), Vol. III, 199., Abdullah bin Hijâzi bin Ibrâhim al-Sharqâwî, Hâashiyah al-Sharqâwñ (t.tp.: Maktabah Shamelah, t.th.), Vol. II, 230., Abdurrahman al-Jazîrî, al-Fiqh 'alâ Madhâhib al-Arba'ah, (Beirut: Dâr al-Kutib al-Ilmîyah, 1971), Vol. IV, 41.
} 
sebagian ulama' yang memilih pendapat tentang keabsahan nikah ketika calon suami tidak mampu membayar mahar mithil. ${ }^{62}$

Namun, Sayyid Sâbiq menyatakan bahwa mahar mithil merupakan alasan sah wali untuk menolak pernikahan anaknya. Artinya, jika calon yang diajukan anaknya tidak dapat membayar mahar yang besarannya sesuai mahar mithil maka wali tidak dikategorikan adal. ${ }^{63}$ Pendapat ini menurut peneliti kurang tepat sebab para ulama' telah jelas menyatakan bahwa mahar adalah hak perempuan sehingga wali tidak memiliki hak untuk menentukan besaran mahar.

Kelima, calon yang diajukan anaknya atau perempuan yang di bawah perwaliannya tidak mengalami cacat atau 'ayb al-nikâh. Ulama' membedakan cacat calon suami yang dianggap menghalangi kewajiban sebagai suami dan cacat yang dianggap tidak menghalangi kewajiban sebagai suami. Menurut Shaykh Syamsuddin Muhammad bin Ahmad alKhatîib al-Shirbînî bahwa cacat fisik yang mengahalangi persetubuhan seperti impotensi tidak dinilai sebagai cacat yang dapat dijadikan alasan wali mujbîr menghalangi pernikahan anaknya dengan calon pilihan suami anaknya selama anaknya tersebut rela dengan keadaan calon suaminya karena urusan persetubuhan adalah hak anaknya (perempuan). Maka wali mujbir yang menghalangi pernikahan anaknya tersebut dianggap wali adal. Sementara cacat yang mengahalangi kewajiban sebagai suami seperti penyakit baras atau juzam dan gila dinilai sebagai cacat yang dapat dijadikan alasan wali mujbir menghalangi pernikahan anaknya. Sehingga wali mujbir yang menghalangi pernikahan anaknya dalam kondisi tersebut tidak dinyatakan adal..$^{64}$

Keenam, ditetapkan oleh hakim (qâdì). Sebuah keniscayaan jika hakim harus terlibat saat terjadi pereseteruan antara kedua belah pihak yang berseteru. Tentunya hal ini bertujuan untuk menghindari tindakan semena-mena dari salah satu pihak terhadap pihak lainnya. Termasuk masalah hukum wali adal. Hakim harus terlibat dalam hal ini untuk memutuskan antara wali dinyatakan adal atau tidak. Sebab hak perwalian dalam pernikahan seharusnya wajib ditunaikan oleh wali sebagaimana pendapat Imam al-Shâfî̀ yang diutarakan oleh Imam al-Nawâwî, ${ }^{65}$

\footnotetext{
62 Abû Bakr bin Muhammad Shatâ al-Dimyâtî̀, Hậshiyah I'ânat al-Tâalibîn 'alâ Halli Alfầzi Fath al-Mu'în, (Beirut: Dâr Ibnu 'Așsâșah, 2005), Vol. III, 308-309.

${ }^{63}$ Sayyid Sâbiq, Fiqh al-Sunnah, (Beirut: Dar al-Fikr, 1992), Vol. VII, 121.

${ }^{64}$ Shams al-Dîn al-Khatîib al-Sharbînî, al-Iqnâ' fi Hịlli Alfâż̆ Abî Shujâ', (Beirut: Dâr al-Fikr, 1990), Vol. III, 199.

${ }^{65}$ Muhyyi al-Dîn Yahyâ Ibnu Sharaf al-Nawâwî, al-Majmû̉ Sharḥ al-Muhadhdhab, (Beirut: Dâr al-Fikr, 1990), Vol. XVII, 322.
} 
Muhammad bin Aḥmad al-Khaṭ̂ib al-Shirbînî, ${ }^{66}$ Abdullah bin Hijâzi bin Ibrâhim al-Sharqâwîi, ${ }^{67}$ Sulaymân bin Muhammad bin Umar alBujayramî, ${ }^{68}$ dan Abdurrahman al-Jazirî. ${ }^{69}$ Campur tangan hakim dalam masalah ini bertujuan agar tidak terjadi permasalahan hukum yang berkepanjangan.

Menurut Shaykh Abdullah bin Hịâai bin Ibrâhim al-Sharqâwî dan Shaykh Sulaymân bin Muhammad bin Umar al-Bujayramî langkah hakim dalam menyelesaikan sengketa dalam pernikahan tersebut adalah dengan memanggil pihak-pihak yang berperkara, yaitu wali, anak perempuan atau perempuan yang di bawah perwalian sang wali dan calon suami pilihan anak perempuan tersebut, lalu memerintahkan wali untuk menikahkan atau dengan menghadirkan bukti-bukti atau saksi-saksi jika sulit untuk megghadirkan wali tersebut. ${ }^{70}$ Sedangkan saksi yang dapat dihadirkan dalam sengketa menurut Shaykh Abû Bakar Muhammad al-Shațâ adalah mereka yang tidak memiliki permusuhan dengan para pihak, yaitu orang yang sedih jika mengetahui kebahagiaan orang yang dimusuhi dan orang yang bahagia dengan kesedihan musuhnya tersebut.

\section{Analisa Ulang Ketentuan Hak Ijbâr}

Dengan adanya ketentuan hukum tentang wali 'adal ini, maka terlihat jelas bahwa hukum Islam sangat melindungi hak-hak perempuan terkait pemilihan calon suaminya. Pertentangan antara wali dengan anak gadisnya dalam menentukan calon suami anak gadis tersebut dapat berakibat pada status wali sebagai wali 'adal jika wali tidak berkenan menyetujui calon yang diajukan anak gadisnya tersebut. Dalam kriteria atau persyaratan wali 'adal terlihat khilaf, bahkan jika terjadi pertentangan antara wali dan anaknya maka menurut sebagian ulama' yang dimenangkan adalah sang anak sebagaimana kriteria kufu' dan mahar

\footnotetext{
${ }^{66}$ Shams al-Dîn al-Khatîib al-Sharbînî, al-Iqnâ' fi Hịlli Alfâąi Abî Shujâ', (Beirut: Dâr al-Fikr, 1990), Vol. II, 413.

67 Abdullah bin Hijâzi bin Ibrâhim al-Sharqâwî, Hâshiyah al-Sharqâwî, (t.tp.: Maktabah Shamelah, t.th.), Vol. II, 230.

68 Sulaymân bin Muhammad bin Umar al-Bujayramî, Al-Bujayramî 'ala al-Khatî̉, (t.tp.: Maktabah Shamelah, t.th.), Vol. III, 230.

69 Abdurrahman al-Jazîrî, al-Figh 'alâ Madhâhib al-Arba'ah, (Beirut: Dâr al-Kutib al-Ilmîyah, 1971), Vol. IV, 41.

70 Abdullah bin Hijâzi bin Ibrâhim al-Sharqâwî, Hâashiyah al-Sharqâwî, (t.th.: Maktabah Shamelah, t.th.), Vol. II, 230., Sulaymân bin Muhammad bin Umar al-Bujayramî, AlBujayramî 'ala al-Khatîb, (t.tp.: Maktabah Shamelah, t.th.), Vol. III, 230.

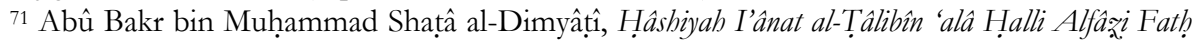
al-Mu’în, (Beirut: Dâr Ibnu 'Aș̣âșahah, 2005), Vol. IV, 289.
} 
mithil. $^{72} \mathrm{Hal}$ ini menunjukkan bahwa hukum Islam sangat melindungi hak-hak perempuan dan meniadakan tindakan kesewenang-wenangan wali.

Adanya ketentuan hukum tentang hak ijbâr teramati bukan sebagai sarana untuk menghilangkan hak-hak perempuan, tetapi teramati sebagai rumusan antisipatif dari para ulama' untuk melindungi anak dari kesalahan menentukan calon suami. Hal ini dapat dilihat dari alasan fuqahâ' shâfi'yyah yang menyatakan bahwa hak ijbâr hanya berlaku pada ayah dan kakek karena selain keduanya dianggap sebagai personal yang tidak memiliki rasa sayang (qâsir al-shafaqah) terhadap anaknya. ${ }^{73}$ Ketentuan hukum tersebut sudah jauh-jauh masa telah diantisipasi agar tidak menjadi alas hukum bagi pernikahan paksa sehingga ulama' juga menentukan persyaratan-persyaratan yang harus dipenuhi oleh wali mujbir. Tetapi persyaratan-persyaratan wali mujbîr ini sepertinya tidak diperhatikan sehingga muncul pemahaman yang mengakar bahwa anak perempuan tidak memiliki hak menentukan ataupun hak menolak paksaan wali.

Illat tentang bolehnya wali memaksa anak gadisnya untuk menikah dengan pilihan walinya adalah sifat kanak-kanak (shighar) menurut hanafíyah dan sifat gadis atau perawan (bikr) menurut selain hanafiyah kedua illat tersebut telah sesuai dengan aturan ushul fiqh, yaitu jelas (zâhir), terukur (mundabit), relevan (munâsib) dan cakupannya tidak hanya pada asl, tetapi dapat diterapkan pada hukum cabang. ${ }^{74}$ Ketentuan illat yang demikian ketat menjadikan konsep qiyâs semakin sulit untuk dikembangkan. Namun konsep munâsabah atau munâsib pada 'illat ternyata dapat memperluas kiprah qiyâs. Selain jelas dan terukur, sifat yang harus ada dalam 'illat adalah keterkaitan atau relevan (munâsib). Artinya, terdapat persesuaian hukum dengan hikmah sebagai tujuan sharîat berupa maslahat, yakni menarik manfaat dan menolak bahaya. ${ }^{75}$

\footnotetext{
${ }^{72}$ Lihat Shamsuddin Muhammad bin Ahmad al-Khatîib al-Shirbînî, Mughni al-Muḅtâj, (t.tp.: Maktaba Shamelah, t.th.), Vol. III, 199., Abdullah bin Hijâzi bin Ibrâhim al-Sharqâwî, Hâshiyah al-Sharqâwî, (t.tp., Maktabah Shamelah, t.th.), Vol. II, 230., Abdurrahman al-Jazîrî, al-Fiqh 'alâ Madhâhib al-Arba'ah, (Beirut: Dâr al-Kutub al-Ilmîyah, 1971), Vol. IV, 41.

73 Muhyi al-Dîn Yahyâ Ibnu Sharaf al-Nawâwî, al-Majmû' Sharh al-Muhadhdhab, (Beirut: Dâr al-Fikr, 1990), Vol. XVI, 165.

74 'Abd al-Wahâb Khallaf, Tlmu Ușûl al-Fiqh, (Kairo: Dâr al-Hadîth, 2003), 68-70., dan Abdul Mun’im Saleh, Hukum Manusia Seabai Hukum Tuban, Berfikir Induktif Menemukan Hakikat Hukum Melalui al-Qawaid al-Fiqbiyyah, (Jogjakarta: Pustaka Pelajar, 2009), 160.

${ }_{75}$ Moh. Dliya'ul Chaq, "Reformulasi Fiqh Melalui Pendekatan 'Urf” Tesis (Surabaya: UIN Sunan Ampel, 2013), 92.
} 
Rumusan munâsib pada 'illat menurut Abdul Mun'im Saleh, menunjukkan adanya keterkaitan antara 'illat dan hikmah atau maslahat. Pemikiran illat hukum berupa maslahat atau hikmah dalam tataran praktis lebih banyak ditunjukkan dalam model penalaran al-qawầid al-fiqhiyyah atau al-ashbah wa al-naz̧âir mengingat mekanisme penalarannya serupa dengan qiyâs 'illat. Hanya saja menurut Abdul Mun'im, qiyâs membatasi kiprahnya pada illat yang konkret, objektif dan terukur. Sedangkan alqawâid al-fiqbiyyah bersandar pada hikmah hukum yang abstrak dan bisa juga subjektif. ${ }^{76}$

Terkait illat hak ijbâr wali, Moh. Dliya'ul Chaq dalam tesisnya menyatakan bahwa gadis dipersonifikasikan sebagai orang yang tidak tahu tentang maslabah nikah karena belum pernah menikah, dan anak kecil dipersonifikasikan sebagai anak yang kurang akalnya. Dengan logika munâsib dan logika al-qawâ'id al-fiqbiyyah, antara 'illat berupa sifat gadis (bikâarah) dan sifat anak-anak (sighâr) memiliki satu hikmah atau maslaḥah yang mempersatukan, yaitu sifat tidak dewasa yang artinya tidak mampu menentukan maslahbah dirinya. ${ }^{77}$ Dengan demikian jelaslah bahwa tujuan ijbâr wali adalah untuk menghindarkan anak gadis dari bahaya. Tujuan ini dapat diistilahkan dengan maqâshid al-sharı’ah, yang lebih khusus dapat diistilahkan dengan maqâshid ijbâr al-walî.

Pertanyaan selanjutnya adalah apakah untuk menghindarkan anak gadis dari bahaya harus dengan hak ijbâr wali? Tentu tidak. Terlebih kondisi pengetahuan dan interaksi social perempuan dahulu dengan perempuan saat ini jelas berbeda jauh. Perempuan saat ini memiliki jangkauan interaksi sosial dan pengetahuan yang lebih luas, bahkan perempuan juga berperan dalam jabatan politik atau pemerintahan. Oleh karenanya, pemaksaan wali untuk menikahkan anak gadisnya dengan landasan motivasi menghindarkan dari bahaya jelas tidak relevan lagi, lebih-lebih logika bahwa diamnya wanita dianggap setuju. Moh. Dliya'ul Chaq dalam tesisnya menyatakan bahwa hadits yang dijadikan landasan hak ijbâr tentang diamnya wanita adalah persetujuannya ini tergolong sebagai ḥadîth yang 'illatnya adalah 'urf, sehingga keberlakuan ḥadìth itu tergantung keberlakuan 'urf. ${ }^{78}$ Artinya, makna diam menurut 'urf masa

\footnotetext{
76 Abdul Mun'im Saleh, Hukum Manusia Seabai Hukum Tuban, Berfikir Induktif Menemukan Hakikat Hukum Melahi al-Qawaid al-Fiqhiyyah, (Jogjakarta: Pustaka Pelajar, 2009), 171.

77 Moh. Dliya'ul Chaq, "Reformulasi Fiqh Melalui Pendekatan 'Urf” Tesis (Surabaya: UIN Sunan Ampel, 2013), 99-101.

78 Moh. Dliya'ul Chaq, "Reformulasi Fiqh Melalui Pendekatan 'Urf” Tesis (Surabaya: UIN Sunan Ampel, 2013), 107-108. Lihat juga Muștafâ Aḥmad Zarqâ, al-Fiqh al-Islâmî fî Thaubih al-Jadìd: al-Madkhal al-Fiqhî al-'Ám, (Damaskus: Dâr al-Qalam, 1998), Vol. II, 910-911.
} 
turunnya ḥadith adalah persetujuan yang kemudian difahami bahwa tanpa persetujuan sama dengan makna diam itu hingga lahirlah ijbâr wali, maka saat ini 'urf telah berubah di mana diam saat ini menurut 'urf tidak menunjukkan tanda setuju. Oleh karenanya, hak jjbâr tidak lagi dapat diterapkan karena hadith itu tidak sesuai dengan 'urf saat ini. Logika berfikir ini diperkuat dengan beberapa kaidah 'urf:

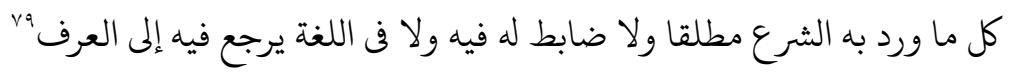

Artinya: Segala ketentuan yang datang dari shara' secara mutlak, tanpa ada batasan dalam shara' dan dalam bahasa, maka dikembalikan pada 'urf'

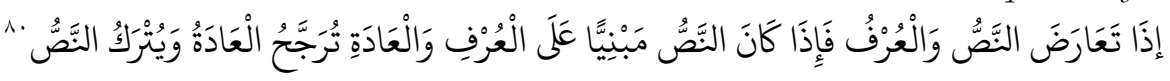
Artinya: "Ketika terjadi pertentangan antara nas dengan kebiasaan maka jikea nas. terbangun atas "urf dan adat maka yang didabulukan adalah "urf dan adat dan meninggalk.an nas."

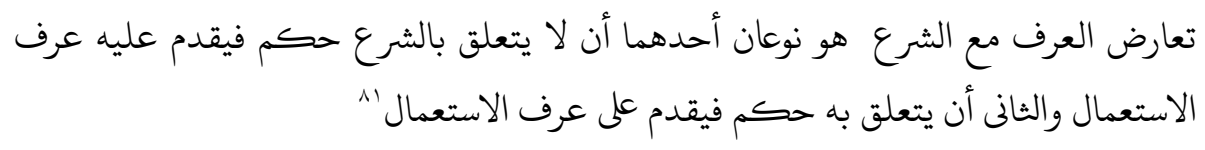

Artinya: "Pertentangan urf dengan shara ada dua macam, 'urf berbubungan dengan bukum dan tidak berbubungan dengan bukum, maka yang didabulukan adalah 'urf.

Selain ketidaksesuaian dengan 'urf, pernikahan paksa malah mengindikasikan ketidakbahagiaan, walaupun ada beberapa fakta pernikahan paksa yang berujung pada kebahagiaan. Namun jika hukum Islam sifatnya zann (prediksi kuat), maka harus ada logika prediksi untuk merumuskan fiqh. Maka pernikahan paksa diprediksi akan menimbulkan perpecahan rumah tangga sebab antara sejak awal pernikahan sudah tidak ada persetujuan untuk melangsungkan pernikahan. Kondisi ini diprediksi sulit mewujudkan maqâshid al-nikâh yang oleh Imam al-Gazâlî diistilahkan dengan fawầid al-nikâh dan diistilahkan Kamâl al-Dîn Muhammad alSîwâsî dengan maqâsìi al-nikâh, yaitu mempunyai anak (keturunan), menyalurkan hasrat seksual yang benar sehingga terhindar dari godaan

\footnotetext{
79 'Abd al-Raḥmân al-Suyûtî, al-Ashbah wa al-Naḍ̂̉ir, (Beirut: Dâr al-Kutub al-ilmiyyah, 1983), 98.

80 'Alî Haydar, Durar al-Hụkekâm Sharḅ Majallat al-Ahkâm, (Beirut: Dâr al-Kutub al-'Ilmiyyah, t.th.), 65 .

81 'Abd al-Raḥmân al-Suyûtîi, al-Ashbah wa al-Nadẩir, 93.
} 
setan, mengatur dan mendidik rumah tangga, memperluas hubungan keluarga dan memenuhi kebutuhan keluarga. ${ }^{82}$

Dengan demikian dapat disimpulkan bahwa hak ijbâr tidak memiliki kekuatan jika harus diterapkan saat ini karena hak ijbâr tetap terbatasi dengan persyaratannya, dengan ketentuan wali adal dan dengan kondisi 'urf saat ini. Namun demikian bukan berarti wali tidak memiliki hak apapun. Adanya ketentuan hukum hak ijbâr dan ketentuan tentang wali nikah menunjukkan bahwa wali punya hak dalam perkawinan anaknya, walaupun prosentasenya lebih besar hak anak. Oleh karenanya Imam alShâfîî tetap menyarankan untuk melakukan musyawarah sebagai cara dan etika yang mulia dalam hal ini, sebagaimana perintah yang sifatnya tidak wajib dari Allah, ${ }^{83}$ yakni surat Ali 'Imrân (3) ayat 159:

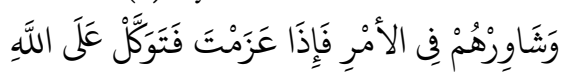

Artinya: "dan bermusyawaratlah dengan mereka dalam urusan itu, kemudian apabila kamu telah membulatkan tekad, Maka bertawakkallah kepada Allah.”

\section{Kesimpulan}

Dari pembahasan di atas dapat disimpulkan bahwa hak ijbâr sejatinya adalah upaya perlindungan terhadap perempuan (anak gadis) namun ketika beralih menjadi hak paksa wali maka tidak dapat diberlakukan karena: Pertama, hak anak gadis dalam figh salaf lebih diutamakan daripada hak wali sebagaimana ketentuan hukum wali 'adal dan persyaratan wali mujbîr. Kedua, 'illat hukum berupa sifat gadis (bikêrah) dan sifat anak-anak (sighâr) dalam kajian munâsib al-íllah dengan pendekatan al-qawầid al-fiqhîah memiliki satu titik kesamaan yaitu illat tidak dewasa yang berarti tidak mampu menentukan maslaḅhah dirinya yang menunjukkan maqâshid menghindarkan anak gadis (perempuan) dari bahaya, dan hal ini sulit tercapai dengan nikah paksa. Ketiga, dasar hukum hak ijbâr adalah ḅadith yang 'illat dalam ḥadith itu adalah 'urf sehingga keberlakuan hadith itu tergantung keberlakuan 'urf. Dan 'urf wanita saat ini sangat berbeda lebih maju dalam hal interaksi sosial, pengetahuan dan peran politik dibandingkan dengan 'urf saat munculnya ḥadith tersebut. Terkhir, musyawarah antara wali dan anak gadis adalah jalan terbaik dan terpuji dalam menentukan calon pasangan anak gadis.

\footnotetext{
82 Abû Hâmid al-Ghazâlî, Ihyâ' 'Ulûm al-Dîn, (Beirut: Dâr al-Ma'rifah, t.th.), Vol. II, 24., Kamâl al-Dîn Muḥammad al-Sîwâsî, Sharḥ Fatḥ al-Qadîr, (Beirut: Dâr al-Fikr, t.th.), Vol. III, 256.

83 Muḥammad Ibnu Idrîs al-Shâfi'î, al-’Um, (Beirut: Dâr al-Ma'rifah, 1993), Vol. V, 18.
} 


\section{Daftar Pustaka}

Anas, Mâlik Ibn. al-Muwatța'. Beirut: Dâr al-Kutub al-'Alamiyyah, 2006.

Andalûsî (al), Abû al-Walîd Muḥammad ibnu Aḥmad bin Rushd alQurtûbî. Bidâyat al-Mujtabid wa Nihâyat al-Muqtasid. Bierut: Dâr alFikr, t.th.

Anșârî (al), Zainuddin Abû Yahyâ Zakariyâ. al-Ghurar al-Babîyah bi Sharḥ al-Babjah al-Wardîyah. Beirut: Dar Kutub Ilmiyah, 1997.

Asqalâni (al), Aḥmad bin Ali bin Hajar. Bulugh al-Marâm. Almanshurah: Dâr al-Manarah, 2003.

Bayhaqî (al), Aḥmad Ibnu al-Khusayn. Sunan al-Bayhaqî al-Kubrâ. Mekkah: Maktabat Dâr al-Bâz, 1994.

Bujayramî (al), Sulaymân bin Muhammad bin 'Umar. Al-Bujayramî 'ala alKhatîb. t.tp.: Maktabah Shamelah, t.th.

Bukhârî (al), Muhammad Ibnu Ismâ'îl. al-Jâmi' al-Sahîth. Beirut: Dâr Ibnu Kathîr, 1987.

Chaq, Moh. Dliya'ul. "Reformulasi Figh Melalui Pendekatan 'Urf” Tesis. Surabaya: UIN Sunan Ampel, 2013.

Dârimî (al), Abû Muḥammad. Sunan al-Dârimî. Beirut: Dâr al-Kitâb al'Arabî, t.th.

Dâruquṭnî (al), 'Alî ibnu 'Umar. Sunan al-Dâruqutnî. Beirut: Dâr alMa'rifah, 1966.

Daud, Abû. Sunan Abû Daud. Beirut: Dâr al-Kitâb al-'Arabî, t.th.

Dimashqî (al), 'Alâ' al-Dîn Abû al-Ḥasan 'Alî al-Mardawî. al-Insâf Fî

Ma'rifati al-Râjị̆ min al-Khilâf 'alâ Madhhab al-Imâm Aḅmad Ibnu Hanbal. Beirut: Dâr Ihyyầ' al-Turâth al-'Arabî, t.th.

Dimyâtî (al), Abû Bakr bin Muhammad Shatâ. Hệshiyah I'ânat al-Ṭâlibîn 'alâ Ḥalli Alfâżi Faț̣ al-Mu'în. Beirut: Dâr Ibnu 'Așsâạahah, 2005.

Ghazâlî (al), Abû Hâmid. Ibyâ' 'Ulûm al-Dîn. Beirut: Dâr al-Ma'rifah, t.th. Hanbal, Ahmmad Ibnu. Musnad Aḥmad Ibnu Hanbal. t.tp.: Muassasah alRisâlah, 1999.

Haydar, 'Alî. Durar al-Hukkkâm Sharh Majallat al-Abkâm. Beirut: Dâr alKutub al-'Ilmiyyah, t.th.

Haḍrami (al), Abdur Raḥmân bin Muhạmmad bin Husayn bin 'Umar Bâ

'Alawî. Bughyat al-Mustarshidîn. t.tp.: Maktabah Shamelah, t.th.

Jawziyyah (al), Ibn Qayyim. Zâd al-Ma'âd. Mesir: Muștafâ al-Bâb alHalabî wa Awlâdih, 1970.

Jazîrî (al), Abdurrahman. al-Fiqh 'alâ Madhâbib al-Arba'ah. Beirut: Dâr alKutub al-Ilmîyah, 1971. 
Khallaf, 'Abd al-Wahâb. Tlmu Usûll al-Fiqh. Kairo: Dâr al-Ḥadîth, 2003.

Maqdisî (al), 'Abd al-Raḥmân Ibn Ibrâhîm Bahâ' al-Dîn. al-'Uddah Sharḥ al-'Umdah. Beirut: Dâr al-Kutub al-'Ilmiyyah, 2005.

Nasâ’î (al), Aḥmad Ibnu Shu'ayb. Sunan al-Nasầî al-Kubrâ. Beirut: Dâr alKutub al-'Ilmiyyah, 1991.

Nawawi (al), Muhyiddin Abû Zakariyya Yahya bin Syaraf. al-Majmû' Sharḥ al-Mubadhdhab. Beirut: Dâr al-Fikr, 1990. . Rawdat al-Tâlibîn. t.tp.: Maktabah Shamelah, t.th.

Nujaym, Ibnu. al-Baḅr al-Rầiq Sharḥ Kanæu al-Daqâंiq. Beirut: Dâr alMa'rifah, t.th.

Qurțûbî (al), Abû 'Umar Yûsuf al-Namrî. al-Istidhkâr al-Jâmi’ li Madbâbib Funqahâ’ al-Amsâr. Beirut: Dâr al-Kutub al-'Tlmiyyah, 2000. al-Kâfì fì Fiqh Abl al-Madinah. Riyaḍ: Maktabat al-Riyâḍ alHadîthiyyah, 1980.

Sâbiq, Sayyid. Fiqh al-Sunnah. Beirut: Dar al-Fikr, 1992.

Saleh, Abdul Mun'im. Hukum Manusia Seabai Hukum Tuban, Berfikir Induktif Menemukan Hakikat Hukum Melalui al-Qawaid al-Fiqbiyyah. Jogjakarta: Pustaka Pelajar, 2009.

Sarkhasî (al). al-Mabsût li al-Sarkhasî. Beirut: Dâr al-Fikr, 2000.

Shâfîî (al), Muhammad Ibnu Idrîs. al- 'Um. Beirut: Dâr al-Ma'rifah, 1993.

Sharbînî (al), Shams al-Dîn al-Khatî̉b. al-Iqnâ' fi Hịili Alfâăi Abî Shujầ. Beirut: Dâr al-Fikr, 1990. . Mughni al-Mubtâj. t.tp.: Maktaba Shamelah, t.th.

Sharqâwî (al), Abdullah bin Hịâzzi bin Ibrâhim. Hâshiyah al-Sharqâwî. t.tp.: Maktabah Shamelah, t.th.

Shaybânî (al), Muḥammad Ibn al-Ḥasan. al-Hujjah 'alâ Abli al-Madînah. Beirut: Dâr al-Kutub al-'Ilmiyyah, 1990.

Sîwâsî (al), Kamâl al-Dîn Muhammad Ibnu 'Abd al-Wâhị. Sharḥ Fatḥ alQadîr. Beirut: Dâr al-Fikr, t.th.

Suyûtị (al), 'Abd al-Raḥmân. al-Ashbah wa al-Nadầir. Beirut: Dâr al-Kutub al-ilmiyyah, 1983.

Tasûlî (al), Abû al-Ḥasan 'Alî ibnu 'Abd al-Salâm. al-Babjah Sharḥ alTuhfah. Beirut: Dâr al-Kutub al-'Ilmiyyah, 1998.

Umar, Nasaruddin. Argumen Kesetaraan Jender Perspektif Al-Qur'an. Jakarta: Dian Rakyat, 2010.

Yahya, Mukhtar. Dasar-Dasar Pembinaan Hukum Fiqh Islam. Bandung: AlMa'arif, 1986.

Zarqâ, Muștafâ Aḥmad. al-Fiqh al-Islâmî fî Thaubih al-Jadîd: al-Madkhal alFiqhî al-'Âm. Damaskus: Dâr al-Qalam, 1998. 